\title{
Actual evapotranspiration and crop coefficients of irrigated lowland rice (Oryza sativa L.) under semiarid climate
}

\author{
Koffi Djaman, ${ }^{1}$ Daran R. Rudnick, ${ }^{2}$ Yonnelle D. Moukoumbi, ${ }^{3}$ Abdoulaye Sow, ${ }^{1}$ Suat Irmak ${ }^{2}$ \\ ${ }^{1}$ Agricultural Science Center, Farmington, NM, USA; ${ }^{2}$ Department of Biological Systems Engineering, \\ University of Nebraska-Lincoln, Lincoln, NE, USA; ${ }^{3}$ Plant Breeder at National Institute of Agricultural \\ Research, Libreville, Gabon
}

\begin{abstract}
Lowland irrigated rice is the predominant crop produced in the Senegal River Valley characterised by very low annual rainfall, high temperatures, and low relative humidity. The Senegal River is shared by Senegal, Mali, Mauritania, and Guinea, and serves as the main source of irrigation water for the adopted double rice cropping system. Developing appropriate resource management strategies might be the key factor for the sustainability of rice production in the region. This study aims to estimate rice seasonal evapotranspiration (ETa), irrigation water requirement, and to develop rice growth stage specific crop coefficients $(\mathrm{Kc})$ to improve rice water productivity. Field experiments were conducted during the hot and dry seasons in 2014 and 2015 at the AfricaRice research station at Fanaye in Senegal. Irrigation water inputs were monitored and actual crop evapotranspiration was derived using the water balance method. Daily reference evapotranspiration (ETo) was estimated using the Penman-Monteith equation and the weather variables were collected at the site by an automated weather station. The results showed that the ETo during the hot and dry season from February $15^{\text {th }}$ to June $30^{\text {th }}$ varied from 4.5 to $9.9 \mathrm{~mm}$ and from 3.7 to $10.8 \mathrm{~mm}$ in 2014 and 2015, respectively, and averaged $6.8 \mathrm{~mm} \mathrm{~d}^{-1}$ in 2014 and $6.6 \mathrm{~mm} \mathrm{~d}^{-1}$ in 2015 . The seasonal irrigation water amount for the transplanted rice was $1110 \mathrm{~mm}$ in 2014 and $1095 \mathrm{~mm}$ in 2015. Rice daily ETa varied from 4.7 to $10.5 \mathrm{~mm}$ in 2014 and from 4.4 to $10.5 \mathrm{~mm}$ in 2015 and averaged $8.17 \mathrm{~mm}$ in 2014 and $8.14 \mathrm{~mm}$ in 2015 . Rice seasonal ETa was $841.5 \mathrm{~mm}$ in 2014 and $855.4 \mathrm{~mm}$ in 2015. The derived
\end{abstract}

Correspondence: Koffi Djaman, Agricultural Science Center, Farmington, NM 87401, USA. Tel.:+15059607757.

E-mail:kdjaman@nmsu.edu

Key words: Rice; irrigation; evapotranspiration; crop coefficients.

Received for publication: 7 July 2017.

Revision received: 2 March 2018.

Accepted for publication: 29 April 2018.

(C) Copyright K. Djaman et al., 2019

Licensee PAGEPress, Italy

Italian Journal of Agronomy 2019; 14:1059

doi:10.4081/ija.2019.1059

This article is distributed under the terms of the Creative Commons Attribution Noncommercial License (by-nc 4.0) which permits any noncommercial use, distribution, and reproduction in any medium, provided the original author(s) and source are credited. rice $\mathrm{Kc}$ values varied from 0.77 to 1.51 in 2014 and 0.85 to 1.50 in 2015. Rice Kc values averaged 1.01, 1.31, and 1.12 for the crop development, mid-season and late season growth stages, respectively. The Kc values developed in this study could be used for water management under rice production during the hot and dry season in the Senegal River Valley.

\section{Introduction}

Rice is the principal staple food widely consumed and a veritable source of calories for humans. Rice is primarily produced under flooded conditions, but it is not an aquatic plant. Rice water use needs to be investigated under climate change conditions due to decreasing trends in available fresh water for agriculture coupled with increasing world population. Rice is an important staple food crop in Senegal and the main crop grown across the Senegal River valley and Delta and 100\% irrigated. Under the semiarid climate conditions in the Senegal River Valley, accurate estimation of rice actual evapotranspiration is fundamental for sustainable water management for improving rice water productivity. Irrigated lowland rice water use differs with agroecosystems, climate, and management practices. Rice gross water use was $2300 \mathrm{~mm}$ in Tanzania with very low water productivity of $0.3 \mathrm{~kg} \mathrm{~m}^{-3}$ (Mdemu et al., 2004). Jehangir et al. (2004) found rice water requirement that varied from 1200 to $1600 \mathrm{~mm}$ in the Pakistan sub-tropical semiarid conditions. Tuong et al. (2005) reported irrigation water inputs from 400 to over $2000 \mathrm{~mm}$ with median values in the range of 1300 to $1500 \mathrm{~mm}$. Hargreaves et al. (2006) reported rice irrigation water requirement of 1788 and $2030 \mathrm{~mm}$ for the wet and dry seasons in the Senegal River Basin, while recent studies reported irrigation requirements of 1110 to $1300 \mathrm{~mm}$ (de Vries et al., 2010) and 863 to $1198 \mathrm{~mm}$ (Djaman et al., 2016a). A clear gap exists between irrigation water use and water requirements for rice production. Rice water use under flooded irrigation is well documented in many Asian countries and other locations across the globe. Seasonal rice actual evapotranspiration (ETa) varied between 400 and $700 \mathrm{~mm}$ in the Philippines (Tabbal et al., 2002) and 540 and $730 \mathrm{~mm}$ in India (Chahal et al., 2007). Rice ETa range of 750-850 $\mathrm{mm}$ was reported by Aguilar and Borjas (2005) and Moratiel and Martinez-Cob (2013) under sprinkler irrigation in Spain. In Italy rice water use was within the range of 700 to $800 \mathrm{~mm}$ (Spanu et al., 2009). Large variation in rice seasonal irrigation requirement is observed among rice hubs and at the same rice production site with regard to interannual variation in climate. Rice seasonal irrigation water requirements varied from 962 to $1114 \mathrm{~mm}$ in Taiwan (Kuo et al., 2006), from 383 to $1148 \mathrm{~mm}$ in the sub basin of Niger River in Benin (Bouraima et al., 2015). Under the semiarid climate in the Senegal River Basin, Djaman et al. (2016a) reported 
rice water requirements values that varied from 863 to $1198 \mathrm{~mm}$ while Terjung et al. (1984) reported rice irrigation water requirements over $1000 \mathrm{~mm}$ in northwest China and $500 \mathrm{~mm}$ in southcentral China. Irrigation water requirements of most paddy fields is high considering water losses by seepage as well as low efficiency of delivered water by most irrigation canals not being sealed.

Rice ET is often estimated by the two-step approach, multiplying reference ET by growth stage specific crop coefficients $(\mathrm{Kc})$ (Jensen, 1968; Jensen et al., 1990; Allen et al. 1998). This method is an alternative to the direct measurements of crop actual evapotranspiration through lysimeters, Bowen ratio energy balance systems, eddy correlation systems, flux profile techniques, and surface renewal (Hatfield, 1990; Rudnick and Irmak, 2014). Rice growth specific Kc values have been developed and reported for the major rice hubs to improve water and nutrient management in the paddy fields. Allen et al. (1998) recommended rice Kc values of $1.05,1.20$, and 0.90 to 0.60 for the crop development, midseason and late season growth periods under continuous flooding irrigation conditions. Kc values of $0.92,1.06$, and 1.03 were reported for sprinkler-irrigated rice under semiarid climate in Spain (Moratiel and Martinez-Cob, 2013). While Arif et al. (2012) reported low rice Kc value of 0.70 for the initial stage, they reported higher midseason, and late season Kc values of 1.24, and 1.22, respectively, under intermittent irrigation and 1.21, and 1.10 under continuous flooding in Indonesia. Similarly, high Kc values of $1.15-1.58,1.44-1.75,1.90-1.96,1.59-1.82$, and 1.0-1.41 for the tillering, panicle initiation, flowering, physiological maturity, and harvesting were reported in India by Choudhury and Singh (2016) reported transplanted flooded rice. In California, Montazar et al. (2017) derived paddy rice Kc values of $1.10,1.00$, and 0.80 for the initial, midseason and late season stages. Although Kc values are developed and proposed for several locations under different climate as aforementioned, a few data and information is available on the sub-Saharan Africa rice hubs. Growth stage specific Kc values are influenced by irrigation regime, management practices, local climate, soil types, and other environmental factors (Allen et al., 1998; Djaman and Irmak, 2013), and therefore, it is important to develop growth stage specific Kc values under local management practices for accurate estimation of crop water use. The objectives of the present study were to estimate rice actual evapotranspiration and to derive rice crop coefficients using the water balance equation for the period of 2014-2015 under semiarid climate at Fanaye in the Senegal River Valley, Senegal.

\section{Materials and methods}

\section{Site description and data collection}

The study was conducted at Fanaye in the Senegal River Valley (SRV) (Senegal, West Africa) during the hot and dry seasons in 2014 and 2015. The experimental site is located on the Africa Rice Centre (AfricaRice) research station at Fanaye $\left(16^{\circ} 32^{\prime}\right.$ $\left.\mathrm{N}, 15^{\circ} 11^{\prime} \mathrm{W}\right)$. Climate at the site is typically Sahelian with 9month dry period from October to June and short wet season from July to September. Temperatures are high from March to July. Typically, rice production takes place twice a year, from February to June in the hot dry season and from August to December in the wet season. The soil type at the station is characterised as a eutric vertisol with high clay content (45 to $65 \%$ ) and a percolation rate of $2.0 \mathrm{~mm} \mathrm{~d}^{-1}$ (Samba, 1998; Haefele, 2001).

Climatic variables at the site were collected between February and June in 2014 and 2015. Daily average wind speed, maximum and minimum air temperature, maximum and minimum relative humidity, incoming solar radiation, and precipitation were measured over a well-watered grass surface using an automated weather station (CimAGRO) installed at the experimental field station. The weather station area is $64 \mathrm{~m}^{2}(8 \mathrm{~m}$ over $8 \mathrm{~m})$. Cynodon dactylon (L.) generally called Bermuda grass was planted and irrigation by basin irrigation. Water is conducted to the plot through PVC pipe and diverted in the middle of the plot. No standing water was allowed within the grass. The frequency of irrigation was twice a week or as needed. Grass was regularly cut and had average height of $12 \mathrm{~cm}$ as recommended. Grass plot was kept weed free with no pest or rodent damage. The automatic agro-weather station CimAGRO is a compact system designed with Institut National de la Recherche Agronomique (INRA) partnership and is equipped with extremely reliable and stable sensors that are interchangeable without programming (plug and play connections) and suitable under difficult weather conditions. All variables were sampled every 60 seconds and recorded on daily basis.

\section{Crop management}

Rice seed of the variety Sahel 108 was pre-germinated on February $15^{\text {th }} 2014$ and 2015 and transplanted on March $7^{\text {th }}$ and $9^{\text {th }}$ in 2014 and 2015, respectively, at the rate of 25 hills $\mathrm{m}^{-2}$. The plot area was $1250 \mathrm{~m}^{2}(25 \times 50 \mathrm{~m})$. Fertilisers in the form of urea, ammonium phosphate, and potassium chloride were applied to achieve 120,26 , and $50 \mathrm{~kg} \mathrm{ha}^{-1}$ of nitrogen $(\mathrm{N})$, phosphorous $(\mathrm{P})$, and potassium $(\mathrm{K})$, respectively. Fertiliser was split and applied as follows: $50 \% \mathrm{~N}, 100 \% \mathrm{P}$, and $100 \% \mathrm{~K}$ were broadcast 14 days after transplanting; the remaining $\mathrm{N}$ fertiliser was split-applied at panicle initiation (25\%) and 10 days before flowering (25\%). Herbicide (propanyl, $6 \mathrm{~L} \mathrm{ha}^{-1}$ ) and manual weeding were used for weed control. The herbicide was applied once at 21 days after sowing and one day before the first $\mathrm{N}$ application; thereafter, plots were kept weed-free by manual weeding. Insecticide (carbofuran [Furadan]) was used at $25 \mathrm{~kg} \mathrm{ha}^{-1}$ for insect-pest control at the start of tillering, panicle initiation, and flowering. A constant water layer of 5 $\mathrm{cm}$ was maintained during the rice vegetative phase while water depth of $10 \mathrm{~cm}$ was maintained during rice reproductive phase. At crop physiological maturity, rice was harvested.

\section{Reference evapotranspiration estimation}

Daily grass-reference evapotranspiration (ETo) was computed using the standardised ASCE form of the Penman-Monteith (ASCEEWRI PM) equation (ASCE-EWRI 2005). The Penman-Monteith reference evapotranspiration equation with fixed stomatal resistance values for both grass and alfalfa-reference surface is:

$E T o=\frac{0.408 \Delta(R n-G)+\gamma C n u 2 /(T+273)(e s-e a)}{\Delta+\gamma(1+C d u 2)}$

where, ETo is reference evapotranspiration $\left(\mathrm{mm} \mathrm{day}^{-1}\right), \Delta$ is slope of saturation vapour pressure versus air temperature curve $(\mathrm{kPa}$ $\left.{ }^{\circ} \mathrm{C}^{-1}\right), R n$ is net radiation at the crop surface $\left(\mathrm{MJ} \mathrm{m}^{-2} \mathrm{~d}^{-1}\right), G$ is soil heat flux density at the soil surface $\left(\mathrm{MJ} \mathrm{m}^{-2} \mathrm{~d}^{-1}\right), T$ is mean daily air temperature $\left({ }^{\circ} \mathrm{C}\right), u_{2}$ is mean daily wind speed at $2 \mathrm{~m}$ height $(\mathrm{m}$ $\left.\mathrm{s}^{-1}\right)$, es is saturation vapour pressure $(\mathrm{kPa}), e a$ is actual vapour pressure $(\mathrm{kPa})$, es $-e a$ is saturation vapour pressure deficit $(\mathrm{kPa})$, $\gamma$ is psychrometric constant $\left(\mathrm{kPa}^{\circ} \mathrm{C}^{-1}\right), \mathrm{Cn}$ is $900{ }^{\circ} \mathrm{C} \mathrm{mm} \mathrm{s}^{3} \mathrm{Mg}^{-1}$ $\mathrm{d}^{-1}, \mathrm{Cd}$ is $0.34 \mathrm{~s} \mathrm{~m}^{-1}$. All parameters necessary for computing ETo were computed according to the procedure developed in FAO-56 by Allen et al. (1998). 


\section{Actual crop evapotranspiration estimation}

Soil water balance equation was used for the calculations of rice ETa and Kc values. ETa between two irrigation events was calculated using a general soil water balance equation:

$P+I+U=R+D \pm \Delta W+E T a$

where, $\mathrm{P}$ is effective rainfall $(\mathrm{mm})$; I is irrigation water applied $(\mathrm{mm})$; $\mathrm{U}$ is upward vertical soil water flux from below the crop root zone $(\mathrm{mm})$; $\mathrm{R}$ is surface run-off $(\mathrm{mm}) ; \Delta \mathrm{W}$ is change in soil water storage in the crop root zone $(\mathrm{mm})$; and $\mathrm{D}$ is deep percolation of water below the root zone $(\mathrm{mm})$, and ETa is actual evapotranspiration (mm).

Effective rainfall in the paddy field was estimated according to Chen et al. (2014):

$P i=Y i d s \leq R d$

where $\mathrm{Rd}$ is daily rainfall data ( $\mathrm{mm} /$ day), $\mathrm{Pi}$ is daily effective rainfall ( $\mathrm{mm} /$ day), Yi is the cut-off water supply days, ds is the requirement for 1 day's irrigation ( $\mathrm{mm} /$ day).

The paddy field was protected by $30 \mathrm{~cm}$ dikes, and therefore, there was no runoff $(\mathrm{R}=0)$. Ground water table at the site is consistently below $3.0 \mathrm{~m}$ with site deep percolation rate (saturated infiltration rate) estimated at $2.0 \mathrm{~mm} \mathrm{~d}^{-1}$ (Haefele et al., 2001; de Vries, 2010; Djaman et al., 2016a). Assuming that the upward flux was negligible because of soil saturation, $\mathrm{R}$ is null and $\Delta \mathrm{W}$ equals zero because of soil saturation due to permanent flooded under lowland basin irrigation conditions from seedling transplanting to crop physiological maturity (de Vries et al., 2010; Pascual and Wang, 2017; Concenço et al., 2018), the equation is reduced to the following form for calculating ETa:

$E T a=P+I-D$

The seasonal ETa was estimated as the sum of the periodic ETa from transplanting to crop physiological maturity.

\section{Crop coefficients development}

Crop coefficients Kc values were determined as suggested by Jenson (1968) and Allen et al. (1998):

$$
K c=\frac{E T a}{E T o}
$$

Transplanted rice growing period was divided into three distinct stages: crop development, mid-season, and late season and average Kc values were determined for each stage.

\section{Results and discussion}

\section{Weather conditions during the study period}

Rice is produced during the hot and dry season that covers the period from mid-February to end June, corresponding to the period of 45-185 days of year (DOY). Average daily temperature was similar for the 2014 and 2015 dry seasons and varied from 19.1 to $35.9^{\circ} \mathrm{C}$ in 2014 and from 19.5 to $37^{\circ} \mathrm{C}$ in 2015 (Figure $1 \mathrm{~A}$ ). Seasonal average temperature was $29.1^{\circ} \mathrm{C}$ in 2014 and $29.8^{\circ} \mathrm{C}$ in
2015 and the total accumulated thermal units (TU) was 2255 and $2268^{\circ} \mathrm{C}$ in 2014 and 2015 , respectively. The lowest temperatures were registered in February and the highest values were registered around 150 DOY late May early June. Daily temperatures were always higher than the rice base temperature of $10^{\circ} \mathrm{C}$ (Tang et al., 2009). The research site is relatively dry and the relative humidity varied from 11.3 to $58.5 \%$ in 2014 and from 11.3 to $61.3 \%$ in 2015 and averaged 39.7 and $40.0 \%$ in the respective years (Figure 1B). There was great fluctuation in relative humidity during the hot and dry season as shown in Figure 1B. Wind speed showed similar patterns in 2014 and 2015, slightly increased during the season and varied from 0.93 to $3.69 \mathrm{~m} \mathrm{~s}^{-1}$ in 2014 and from 0.83 to $4.47 \mathrm{~m} \mathrm{~s}^{-1}$ in 2015 (Figure 1C). Seasonal average wind speed was $1.93 \mathrm{~m} \mathrm{~s}^{-1}$ in both years. Seasonal solar radiation varied from 10.23 to $26.15 \mathrm{MJ}$ $\mathrm{m}^{-2}$ in 2014 and from 8.85 to $25.52 \mathrm{MJ} \mathrm{m}^{-2}$ in 2015 (Figure 1D),
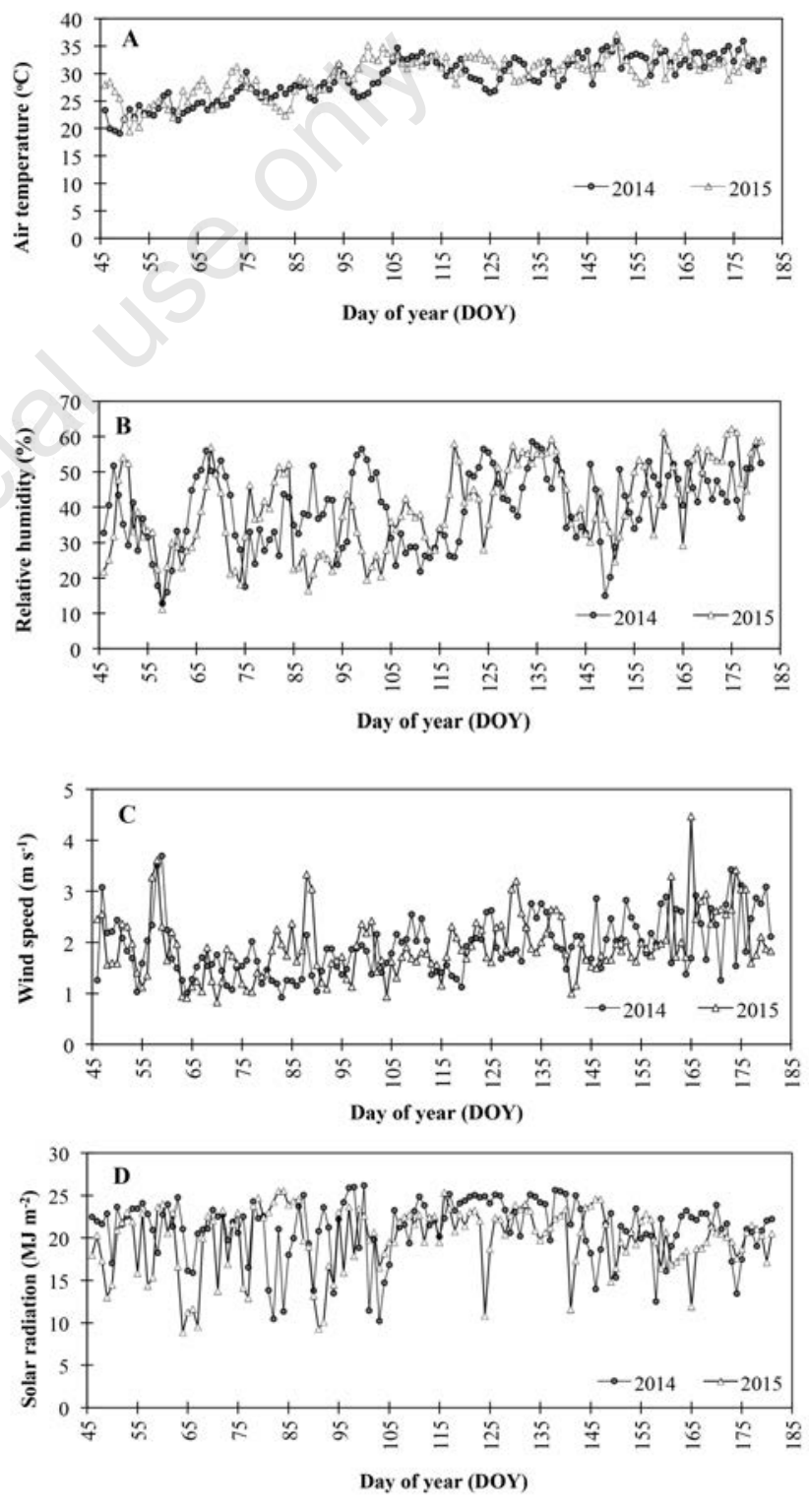

Figure 1. Daily average air temperature (A), relative humidity (B), wind speed at $2 \mathrm{~m}$ height $(C)$, and incoming solar radiation (D) measured at the experimental site for the 2014 and 2015 dry seasons. 
and averaged 21.18 and $19.87 \mathrm{MJ} \mathrm{m}^{-2}$ in 2014 and 2015, respectively. Overall, climatic conditions were similar during the 2014 and 2015 hot seasons at the experimental site and favourable to rice growth and development.

\section{Evolution in the daily reference evapotranspiration during rice growing seasons}

The Penman-Monteith grass ETo during the hot and dry season from February $15^{\text {th }}$ to June $30^{\text {th }}$ varied from 4.5 to $9.9 \mathrm{~mm} \mathrm{~d}^{-1}$ in 2014 and 3.7 to $10.8 \mathrm{~mm} \mathrm{~d}^{-1}$ in 2015 and averaged $6.8 \mathrm{~mm} \mathrm{~d}^{-1}$ in 2014 and $6.6 \mathrm{~mm} \mathrm{~d}^{-1}$ in 2015. Daily ETo showed the same trend as daily temperature, relative humidity, wind speed, and incoming solar radiation measured at the experimental site (Figure 2). Total seasonal ETo was $920.6 \mathrm{~mm}$ in 2014 and $900.8 \mathrm{~mm}$ in 2015 . Therefore, on average, there was $2.9 \%$ reduction in daily ETo and $2.1 \%$ reduction in seasonal ETo in 2015 as compared to the 2014 average daily ETo and seasonal ETo.

\section{Rice seasonal irrigation water requirement}

Cumulative irrigation in 2014 and 2015 is presented in Figure 3. Irrigation depth of $50 \mathrm{~mm}$ was applied before seedlings transplanting, and thereafter, water input amount varied from 30 to $110 \mathrm{~mm}$ in 2014 and from 20 to $100 \mathrm{~mm}$ in 2015 . Total of 22 and 25 irrigation events were registered during the 2014 and 2015 hot and dry seasons, respectively. The greatest depth of irrigation water was applied during the rice reproductive phase in both years to maintain $100 \mathrm{~mm}$ of standing water within the rice field to reduce spikelet sterility. Dry season seasonal rice irrigation amount from seedlings transplanting to crop maturity was 1110 and $1095 \mathrm{~mm}$ in 2014 and 2015, respectively. The total irrigation amount per season is quite high due to the high local evaporative demand in the semiarid climate in the Senegal River Valley as reported by Djaman et al. $(2015,2016 b)$ and are supposed to increase due to significant increasing trends in temperature and decreasing trends in relative humidity in the Senegal River Basin (Djaman et al., 2016c). West Africa is shifting to drier conditions due to changes in the general atmospheric circulation as indicated by Nicholson and Grist (2001). The results of this study are in agreement with Djaman et al. (2016a) who found dry season irrigation water requirements varying from 886 to $1198 \mathrm{~mm}$ as a function of nitrogen applied rate and year. Similarly, de Vries et al. (2010) reported seasonal rice irrigation requirement under flooded production of 1110 and 1330 $\mathrm{mm}$ at the same agro-ecological region. In contrast, Jehangir et al. (2004) reported higher values of rice water requirement varying from 1200 to $1600 \mathrm{~mm}$ under semiarid conditions in Pakistan. Extremely high seasonal rice irrigation requirement of $2030 \mathrm{~mm}$ was reported for the dry season in the Senegal River Basin (Hargreaves et al., 1986) and 2000 to $2300 \mathrm{~mm}$ was reported in Greece by Lekakis et al. (2015).

\section{Rice daily and seasonal actual evapotranspiration}

Daily rice ETa varied from 4.7 to $10.5 \mathrm{~mm}$ in 2014 and from 4.4 to $10.5 \mathrm{~mm}$ in 2015 (Figure 4). Daily ETa increased from 4.4 to 8.0 $\mathrm{mm}$ from transplanting to tillering stage (44 days after transplanting, DAT). Daily ETa was stable averaging $10 \mathrm{~mm} \mathrm{~d}^{-1}$ from 43 DAT to $74 \mathrm{DAT}$, which corresponded to rice reproductive phase constitutes of panicle initiation, booting and flowering stages. As rice plant develops, the rice actual evapotranspiration rate increases (Figure 4) and reaches its maximum rate at plant full development stage corresponding to crop mid-season stage (Allen et al., 1998; Djaman et al., 2013; Djaman et al., 2016a). Rice growing cycle was 103 days in 2014 and 105 days in 2015. Average growing season daily ETa was $8.17 \mathrm{~mm}$ in 2014 and $8.14 \mathrm{~mm}$ in 2015. Dry season average rice daily ETa of 6 to $7 \mathrm{~mm}$ was reported in most of tropics (Maclean et al., 2002). Sivapalan (2015) found seasonal average daily rice ETa of $9.93 \mathrm{~mm}$ in Australia. A strong relationship between rice daily ETa and DAT was observed with coefficient of determination $\left(\mathrm{R}^{2}\right)$ of 0.82 (Figure 4 ). On a seasonal basis, rice ETa estimated from the water balance method was $841.5 \mathrm{~mm}$ in 2014 and $855.4 \mathrm{~mm}$ in 2015. These results are within the range of an earlier study by Djaman et al. (2016a) who reported dry season rice ETa from 837 to $929 \mathrm{~mm}$ and from 803 to $896 \mathrm{~mm}$ as a function of nitrogen applied rate and year. Sudhir-Yadav et al. (2011) reported rice ETa ranged from 749 to $811 \mathrm{~mm}$ under semiarid climate in India and Choudhury and Singh (2016) found rice ETa varying from 781 to $899 \mathrm{~mm}$ in the semiarid climate in Indo-Gangetic Plains in India. Under similar climatic condition, Hendrickx et al. (1986) found seasonal rice ETa of 720 to $910 \mathrm{~mm}$ in the Office du

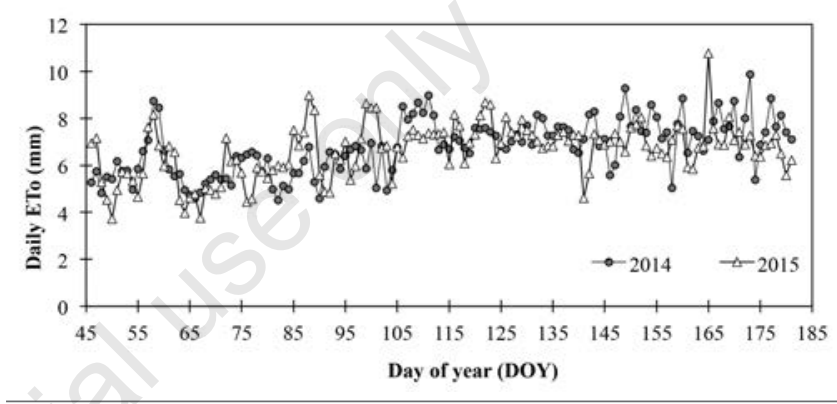

Figure 2. Daily grass reference evapotranspiration (ETo) as a function of day of year (DOY) for the 2014 and 2015 dry seasons.

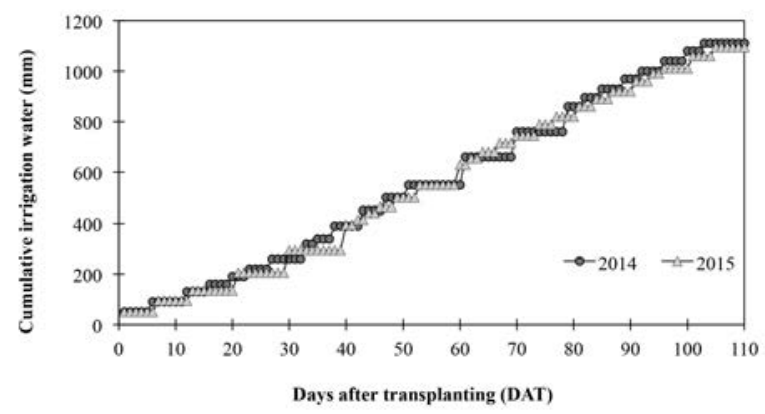

Figure 3. Cumulative irrigation amounts applied during rice hot and dry seasons in 2014 and 2015.

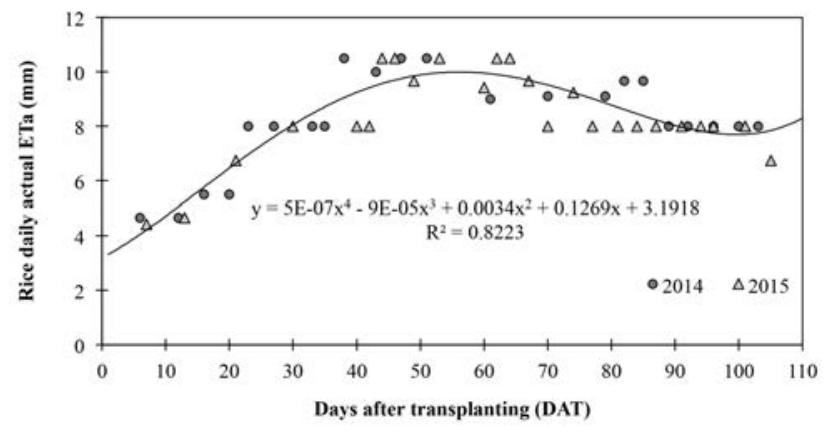

Figure 4. Rice actual evapotranspiration (ETa) during the hot and dry season in 2014 and 2015. 
Niger in Mali and Poussin et al. (2005) reported rice ETa of 802 $\mathrm{mm}$ at Nakhlet in Mauritania. In contrast, lower paddy rice season ETa of 681 to $813 \mathrm{~mm}$ was observed in California (Montazar et al., 2017) and relatively high rice ETa value of $1350 \mathrm{~mm}$ was reported in northern Greece (Lekakis et al., 2015).

\section{Rice crop coefficients}

Rice Kc values developed by the water balance method varied from 0.77 to 1.51 in 2014 and 0.85 to 1.50 in 2015 (Figure 5). Rice $\mathrm{Kc}$ increased from 0.77 to 1.51 with crop development from transplanting to full canopy coverage (55 DAT), and thereafter, Kc decreased to 0.93 at crop physiological maturity. Rice Kc had fiveorder polynomial correlation with DAT and TU with $\mathrm{R}^{2}$ of 0.76 and 0.75 , respectively (Figure 5). As a function of $\mathrm{TU}, \mathrm{Kc}$ increased and reached its maximum at thermal units of 829 to $1025^{\circ} \mathrm{C}$, corresponding to rice reproductive stage, and thereafter, decreased to TU of $2096^{\circ} \mathrm{C}$ in 2014 and $2016^{\circ} \mathrm{C}$ in 2015 (Figure 5). Rice season duration varied greatly with years and low temperatures can persist into late march or early April. Consequently, the two-step ETa approach $(\mathrm{ETa}=\mathrm{Kc} \times \mathrm{ETo})$ may lead to under-oroverestimation of ETa and irrigation requirements. Therefore, growth stage $\mathrm{Kc}$ as a function of TU may be more useful, since the sum of accumulated degree-days is strongly related to crop physiology. Rudnick and Irmak (2014) reported that accumulated degree days does not account for all ET influencing factors, but it does provide a means of reducing inter-annual differences in climatic conditions impacting ET. The relationships between Kc vs DAT and Kc vs TU could be used to provide the daily Kc of irrigated lowland rice in the semiarid climate and management practices similar to the conditions of the present study. Moreover, the relationship Kc vs TU could be used despite rice cropping season because rice TU is related to crop phenology and physiology. Over two seasons, rice Kc values averaged 1.01, 1.31, and 1.12 for the
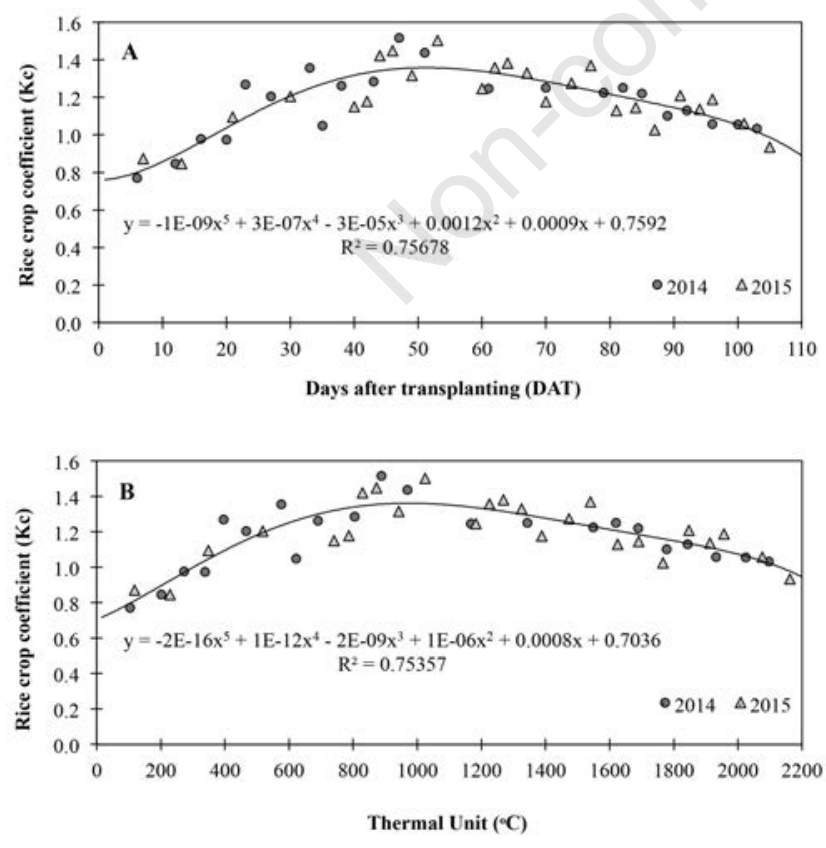

Figure 5. Rice crop coefficient $(\mathrm{Kc})$ as a function of $(\mathrm{A})$ days after transplanting (DAT) and (B) thermal unit for the 2014 and 2015 dry seasons. crop development, mid-season, and late season growth periods, respectively. Generally, crop coefficient values have trapezoidal relationship with days after planting. Crop growth and development season is composed of the initial, development, mid and late seasons. Crop Kc is theoretically constant (Kci) during the initial crop growth stage, it increased gradually from Kci to Kcmid during crop development state and reaches its maximum values during crop mid-season, and decreased graduation from Kc mid to Kc end during crop late season (Allen et al., 1998). Allen et al. (1998) proposed lowland rice Kc values of 1.05, 1.20 and 0.6 for Kci, Kcmid and Kcend, respectively. The results are similar to the Kc values reported by previous studies. Montazar et al. (2017) reported paddy rice Kc values of $1.10,1.00$, and 0.80 for the initial-growth, midseason, and late-season stages in the Sacramento valley in California under hot and dry summer conditions. Mohan and Arumugam (1994) reported rice Kc values of 1.15, 1.23, and 1.14 for the initial-growth, midseason, and late-season stages, while Allen et al. (1998) suggested lower Kc values of 1.05, 1.20, and 0.90 to 0.60 for the respective stages. Lower crop development $\mathrm{Kc}$ of 0.78 and higher mid-season Kc of 1.58 were reported in Korea by Seung et al. (2006). Mohan and Arumugam (1994) reported rice $\mathrm{Kc}$ values for four rice crop growth stages (initial growth, crop development, reproductive, and maturity) of 1.15, 1.23, 1.14, and 1.02, respectively, under sub-humid tropical climate in India. Moratiel and Martínez-Cob (2013) reported rice crop coefficients for the initial (Kcini), mid-season (Kcmid) and season stages (Kcend) as $0.92,1.06$, and 1.03, respectively, under semiarid conditions of Northeast Spain. Tyagi et al. (2000) estimated values of crop coefficient for rice at the four crop growth stages (initial, crop development, reproductive and maturity) were 1.15, 1.23, 1.14 and 1.02 , respectively, at Karnal, India. For the aforementioned Kc values, Kc increases linearly from the initial $\mathrm{Kc}$ value to the mid-season Kc value during the development stage, and decreases linearly from the mid-season $\mathrm{Kc}$ value to the $\mathrm{Kc}$ end value during the late season stage. Third order polynomial relationship between $\mathrm{Kc}$ and the accumulated thermal unit was reported for soybean by Irmak et al. (2013, 2015). Similar relationship was reported for maize in Nebraska USA (Djaman and Irmak., 2013), cotton in Mississippi (Fisher, 2012), and for dry bean (Phaseolus vulgaris L.) in Brazil (Medeiros et al., 2016). The Kc values developed in this study could be used for water management under rice production during the hot and dry season in the Senegal River Valley.

\section{Conclusions}

This study aims to estimate irrigation water requirement of lowland irrigated rice and to develop rice crop coefficients $(\mathrm{Kc})$ for better water management in the Sahelian zone as the Senegal River Valley. Rice seasonal irrigation was $1110 \mathrm{~mm}$ in 2014 and 1095 $\mathrm{mm}$ in 2015 and the seasonal rice actual evapotranspiration (ETa) was $841.5 \mathrm{~mm}$ in 2014 and $855.4 \mathrm{~mm}$ in 2015. The derived rice Kc values varied from 0.77 to 1.51 in 2014 and 0.85 to 1.50 in 2015 . Average rice Kc values for the crop development, mid-season, and late season stages were $1.01,1.31$ and 1.12 , respectively. The $\mathrm{Kc}$ values developed in this study could be used by irrigators, engineers, university researchers, and students to improve water management under continuous flooded rice production during the hot and dry season in the Senegal River Valley and similar climate, soil, and management conditions. 


\section{References}

Aguilar M, Borjas F, 2005. Water use in three rice flooding management systems under Mediterranean climatic conditions. Spanish J. Agric. Res. 3:344-51.

Allen RG, Pereira LS, Raes D, Smith M, 1998. Crop evapotranspiration: guidelines for computing crop water requirements. Irrigation and drainage Paper No. 56. FAO, Rome, Italy.

Arif M, Shehzad MA, Bashir F, Tasneem M, Yasin G, Iqbal M, 2012. Boron, zinc and microtone effects on growth, chlorophyll contents and yield attributes in rice (Oryza sativa L.) cultivar. Afr. J. Biotechnol. 11:10851-8.

ASCE-EWRI, 2005. The ASCE standardised reference evapotranspiration equation. In: Allen RG, Walter IA, Elliot RL (eds) Environmental and Water Resources Institute (EWRI) of the American Society of Civil Engineers, ASCE, Standardization of reference evapotranspiration task committee final report. American Society of Civil Engineers (ASCE), Reston, USA.

Bouraima AK, Weihu Z, Chaofu W, 2015. Irrigation water requirements of rice using Cropwat model in Northern Benin. Int. J. Agric. Biol. Eng. 8:58-64.

Chahal GBS, Sood A, Jalota SK, Choudhury BU, Sharma PK, 2007. Yield: evapotranspiration and water productivity of rice (Oryza sativa L.) wheat (Triticum aestivum L.) system in Punjab-India as influenced by transplanting date of rice and weather parameters. Agric. Water Manage. 88:14-27.

Chen FW, Liu CW, Chang FJ, 2014. Improvement of the agricultural effective rainfall for irrigating rice using the optimal clustering model of rainfall station network. Paddy Water Environ. 12:393-406.

Choudhury BU, Singh AK, 2016. Estimation of crop coefficient of irrigated transplanted puddled rice by field scale water balance in the semi-arid Indo-Gangetic Plains, India. Agric. Water Manage. 176:142-50.

Concenço G, Parfitt JMB, Moisinho IS, Bueno MV, da Silva JT, Concenço SE, 2018. Rice yield components under water stress imposed at different growth stages. J. Agric. Sci. 10:290-7.

de Vries ME, Rodenburg J, Bado BV, Sow A, Leffelaar PA, 2010. Giller, K.E. Rice production with less irrigation water is possible in a Sahelian environment. Field Crops Res. 116:154-64.

Djaman K, Irmak S, 2013. Actual crop evapotranspiration and alfalfa- and grass- reference crop coefficients of maize under full and limited irrigation and rainfed conditions. J. Irriga. Drain. Engine. 139:433-46.

Djaman K, Irmak S, Rathje WR, Martin DL, Eisenhauer DE, 2013. Maize evapotranspiration, yield production function, biomass, grain yield, harvest index, and yield response factors under full and limited irrigation. Trans. ASABE 56:273-93.

Djaman K, Mel VC, Balde AB, Bado BV, Diop L, Manneh B, Mutiibwa D, Rudnick D, Irmak S, Futakuchi K, 2016a. Evapotranspiration, irrigation water requirement and water productivity of rice (Oryza sativa L.) in the Sahelian environment. Paddy and Water Environ. 15: 469-82.

Djaman K, Tabari H, Balde AB, Diop L, Futakuchi K, Irmak S, 2016b. Analyses, calibration and validation of evapotranspiration models to predict grass reference evapotranspiration in the Senegal River Delta. J. Hydrol. Regional Stud. 8:82-94.

Djaman K, Balde AB, Rudnick DR, Ndiaye O, Irmak S, $2016 \mathrm{c}$. Long-term trend analysis in climate variables and agricultural adaptation strategies to climate change in the Senegal River Basin. Int. J. Climatol. 37: 2873-88.

Djaman K, Balde AB, Sow A, Muller B, Irmak S, N'Diaye MK,
Manneh B, Moukoumbi YD, Futakuchi K, Saito K, 2015. Evaluation of sixteen reference evapotranspiration methods under sahelian conditions in the Senegal River Valley. J. Hydrol. Region. Stud. 3:139-59.

Fisher DK, 2012. Simple weighing lysimeters for measuring evapotranspiration and developing crop coefficients. Int. J. Agric. Biol. Eng. 5:35-43.

Haefele SM, 2001. Improved and sustainable nutrient management for irrigated rice-based cropping systems in West Africa. Hamburger bodenkundliche arbeiten. Universitat Hamburg, Hamburg, Germany.

Haefele SM, Wopereis MCS, Donovan C, Maubuisson J, 2001. Improving the productivity and profitability of irrigated rice production in Mauritania. Eur. J. Agron. 14:181-96.

Hargreaves GL, Hargreaves GH, Riley JP, 1986. Irrigation water requirements for Senegal River Basin. J. Irrig. Drain. Engine. 1:265-75.

Hatfield JL, 1990. Methods of estimating evapotranspiration. In: B.A. Stewart and D.R. Nielsen (Eds.), Irrigation of agricultural crops. Agronomy monograph, no. 30. American Society of Agronomy (ASA), Crop Science Society of America (CSSA), and Soil Science Society of America (SSA), Madison, WI, USA, pp. 435-474.

Hendrix JE, Linden JC, Smith DH, Ross CW, Park IK, 1986. Relationship of preanthesis fructan metabolism to grain numbers in winter wheat (Triticum aestivum L.). Austr. J. Plant Physiol. 13:391-8.

Irmak S, Djaman K, Sharma V, 2015. Evapotranspiration and single (normal) and basal crop coefficients of winter wheat (Triticum aestivum L.). Trans. ASABE 58:1047-66.

Irmak S, Odhiambo LO, Specht JE. Djaman K, 2013. Hourly and daily single and basal evapotranspiration crop coefficients as a function of growing degree days, days after emergence, leaf area index, fractional green canopy cover, and plant phenology for soybean. Trans. ASABE 56:1785-803.

Jehangir W, Turral H, Masih I, 2004. Water productivity of rice crop in irrigated areas. 4th International Crop Science Congress, Brisbane, Australia. Available from: http://www. cropscience.org.au/icsc

Jensen ME, 1968. Water consumption by agricultural plants. In: Kozlowski TT (Ed.), Water deficits and plant growth. Academic, New York, NY, USA, 2:1-45.

Jensen ME, Burman RD, Allen RG, 1990. Evapotranspiration and Irrigation Water Requirements. ASCE Manuals and Reports on Engineering Practice No. 70, Am. Soc. Civil Engr. New York, NY, USA, pp. 332.

Kuo S, Ho S, Liu C, 2006. Estimation irrigation water requirements with derived crop coefficients for upland and paddy crops in China Irrigation Association, Taiwan. Agric. Water Manage. 82:433-45.

Lekakis E, Aschonitis V, Pavlatou-Ve A, Papadopoulos A, Antonopoulos V, 2015. Analysis of temporal variation of soil salinity during the growing season in a Flooded Rice Field of Thessaloniki Plain-Greece. Agronomy 5:35-54.

Maclean JL, Dawe DC, Hardy B, Hettel GP, 2002. Rice almanac: source book for the most important economic activity on earth. 3rd Edition. CABI Publishing.

Mdemu MV, Magayane MD, Lankford B, Hatibu N, Kadigi RMJ, 2004 Conjoining rainfall and irrigation seasonality to enhance productivity of water in rice irrigated farms in the Upper Ruaha River Basin, Tanzania. Phys. Chem. Earth. 29:1119-24.

Medeiros GA, Luiz AD, Felipe HF, 2016. Growth, development, and water consumption of irrigated bean crop related to grow- 
ing degree-days on different soil tillage systems in Southeast Brazil. Int. J. Agron. ID 8065985.

Mohan S, Arumugam N, 1994. Irrigation crop coefficients for lowland rice. Irrig. Drain. Syst. 8:159-76.

Montazar A, Rejmanek H, Tindula G, Little C, Shapland T, Anderson F, Inglese G, Mutters R, Linquist B, Greer CA, Hill J, Snyder RL, 2017. Crop coefficient curve for paddy rice from residual energy balance calculations. J. Irrig. Drain. Engine. 143:1-1.

Moratiel R, Martınez-Cob A, 2013. Evapotranspiration and crop coefficient of rice (Oriza sativa L.) under sprinkler irrigation in a semi-arid climate determined by the surface renewal method. Irrig. Sci. 31:411-22.

Nicholson SE, Grist JPA, 2001. Conceptual model for understanding rainfall variability in the West African Sahel on interannual and interdecadal time-scales. Int. J. Climatol. 21:1733-57.

Pascual VJ, Wang YM, 2017. Impact of water management on rice varieties, yield, and water productivity under the system of rice intensification in Southern Taiwan. Water 9:1-15.

Poussin JC, Diallo Y, Legoupil JC, Sow A, 2005. Increase in rice productivity in the Senegal River Valley due to improved collective management of irrigation schemes. Agron. Sustain. Develop. 25:225-36.

Rudnick DR, Irmak S, 2014. Impact of nitrogen fertiliser on maize evapotranspiration crop coefficients under fully irrigated, limited irrigation, and rainfed settings. J. Irrig. Drain. Engine. 140:04014039.

Samba DR, 1998. Riziculture et dégradation des sols en vallée du fleuve Sénégal: analyse comparée des fonctionnements hydrosalins des sols du delta et de la moyenne vallée en simple et double riziculture. These de Doctorat, Université Cheikh Anta
Diop, Dakar, Senegal.

Seung H, Jin-Yong YC, Min Won J, 2006. Estimation of paddy rice crop coefficients for Penman-Monteith and FAO modified Penman method. ASABE Annual Int. Meeting, ASABE, St. Joseph, MI, USA.

Sivapalan S, 2015. Water balance of flooded rice in the tropics, irrigation and drainage - sustainable strategies and systems. InTech. Available from: http://www.intechopen.com/ books/irrigation-and-drainage-sustainable-strategies-andsystems/water-balance-of-flooded-rice-in- the-tropics

Spanu A, Murtas A, Ballone F, 2009. Water use and crop coefficients in sprinkler irrigated rice. Ital. J. Agron. 4:47-58.

Sudhir-Yadav G, Humphreys E, Kukal SS, Walia, US. 2011. Effect of water management on dry seeded and puddled transplanted rice: part 1: crop performances. Field Crops Res. 120:112-22.

Tabbal DF, Bouman BAM, Bhuiyan SI, Sibayan EB, Sattar MA, 2002. On-Farm strategies for reducing water input in irrigated rice; case studies in the Philppine. Agric. Water Mange. 56:93-112.

Tang L, Zhu Y, Hannaway D, Meng Y, Liu L, Chen L, 2009. RiceGrow: a rice growth and productivity model. NJASWageningen J. Life Sci. 57:83-92.

Terjung WH, Hayes JT, Ji HY, Ser B, 1984. Crop water requirements for rainfed and irrigated rice (Paddy) in China. Arch. Met. Geoph. Biocl. 34:181.

Tuong TP, Bouman BAM, Mortimer M, 2005. More rice, less water integrated approaches for increasing water productivity in irrigated rice-based systems in Asia. Plant Prod. Sci. 8:231-41.

Tyagi NK, Sharma DK, Luthra SK, 2000. Determination of evapotranspiration and crop coefficients of rice and sunflower with lysimeter source. Agric Water Manage. 45:41-54. 